\title{
Economic Assessment of Peshkopia Thermal Waters
}

\author{
M.Sc. Fatbardh Cena
}

PhD Candidate, University of Tirana; Email: cenafatbardh@gmail.com

\section{Doi:10.5901/ajis.2016.v5n1p271}

\section{Abstract}

\begin{abstract}
Albania is rich with mineral and thermal springs, which have particular curative importance due to high temperature and salt they contain. Among these sources, quite popular also are curative thermal waters as they are known "Spa of Peshkopia". Raised in these waters is a curative balneary complex, consisting of 44 individual cabins and some therapeutic cabinets. These sources act positively in the human body and are used to treat some diseases, especially rheumatism and skin diseases. Their presence, in addition to curative abilities of diseases, has made the surrounding area taking the form of a town from the many buildings and hotels turning into a source of income for many families. This balneal center with its curative values, mud and thermal water pool, located near the highest in Albania Korab mountains, has the capacity to turn in a curative and most important tourism center in Albania. Main targets of this article are the evidence of their curative and economical values and showing a general panorama over their management and problems that they have. Also, I have bring some recomandations that how this center can transform in a very important curative center in Albania. The method that is used for this article mainly is exploitation of literature like touristic guides, publications, leaflets; materials from the balnear center, interwies with directors and workers of this center and working on the ground. The reason that I have presented this topic is that actually there are no scientific researches over the economical rating of this balnear center.
\end{abstract}

Keywords: thermal waters, balneal center, curative tourism, resort, accommodation.

\section{Introduction}

Thermal waters of Peshkopi represent a geological site of regional importance. They are included in the list for protection as natural monuments of albanian nature of Dibra district (DCM $676 \mathrm{dt}$. 20.12.2002). They constitute a balnear comples, not only for Albanians but for the neighbour countries as well.

Curative balneary complex of Peshkopi thermal waters contains 44 individual cabins and six cabinets treatment as medical cabinets through mud sulfur, cabinet therapy (medications through rays, the chinese therapy and massage therapy), treatment by movement and massage friction, gynecology cabinet, cabinet respiratory therapy and two rooms for handling urgent cases (Municiality Peshkopi: 2010).

It is known that Peshkopi thermal waters were used as helpful and curative waters since the 1600s, when they were used by the province and beyond consistently for the curative effects. Traditions are transmitted from generation to generation for their curative effect until around 1870, when they began to be used and maintained by the community of the province. People with knowledge in folk medicines, have recommended to use for certain diseases. On 1928 Ahmet Zogu, has built to cover the first pond, which began to be used by town hall. In 1953 starts its scientific use and built the first environment for bathtubs and washing and the first hotel for patients was built. On 1989 was built a modern complex, the first in Albania, with about 50 tanks and cabinets therapy (Daci: 2006).

\section{Location of the Thermal Waters}

Peshkopi thermal waters are located in northeastern Albania making part in the administrative division of the municipality and district of Dibër. There are about two kilometers from the city of Peshkopi, in its eastern part. They are included in Korabi geological-tectonical zone. They have the following geographical coordinates: $41^{\circ} 42^{\prime} 10^{\prime \prime}$ north latitude and $20^{\circ} 27^{\prime} 15^{\prime \prime}$ longitude (Daci: 2006). Their temperature varies between $35^{\circ} \mathrm{C}-43.5^{\circ} \mathrm{C}$. They have a flow of about 14 liter per second. Thermal waters get up to the surface in contact of gypsum with flisch formation. Their waters contain $600 \mathrm{mg} / \mathrm{l}$ $\mathrm{H}_{2} \mathrm{~S}$ and $3800-4500 \mathrm{mg} / \mathrm{l}$ mineral resources (Albanian Academy of Sciences: 1990).

Along with Banja torrente, there are four thermal springs, close to each other. These springs are related to the gypsym diapir dome of Permian-Triassic age. Gypsum outcrop forms a diapiric dome, which is surrounded by a shistouse flysch of Upper Eocene-to Lower Oligocene. Thermal springs there are associated with the seismoactive tectonic belt of 
Ohrid Lake-Dibër. With this generation, are related tectonic thermal springs of Kosovrasti and Banjishta northwest of Dibër, in Macedonia. The springs are of great flow. Among them, that spring, which has high temperature, it is a debit of 14 liters per second. The other water springs are cool up to $12{ }^{\circ} \mathrm{C}$. Where thermal waters flow gypsum dive below the area of free movement of water, water everywhere under pressure. Thermal springs get up to the surface just in the contact of gypsum with flysch formations. When gypsum dive below the area of free movement of water, notice the presence of $\mathrm{H}_{2} \mathrm{~S}$ (Polytechnic University of Tirana: 2004).

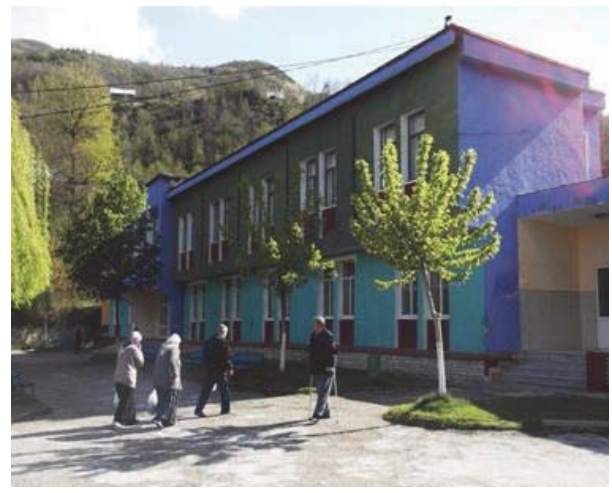

Figure 1. Peshkopi spa tourism center.

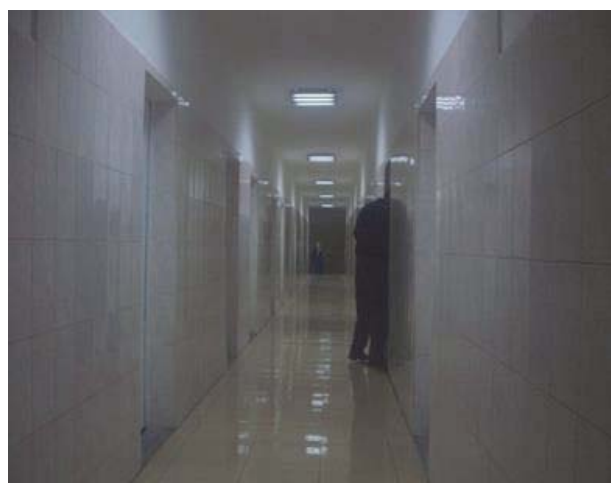

Figure 2. Facilities at balneal center.

\section{The Values of their Healing}

Curative properties of thermal water deal with the following ways:

1. With thermal spa water for 10-15 minutes for these diseases: chronic rheumatism, degenerative rheumatism, arthralgias, chronic neuritis, spondilosis and spondilartrosis, tendons, bursitis, traumatic conditions after reponura accidents, some gynecological diseases as primary and secondary infertility, chronic andesite, chronic endometritet, some skin diseases like psoriasis, skin mycotic diseases etc.

2. By drinking thermal water, the hipoacided hiperacide gastritis, stomach ulcers and chronic deudenit, konstipacionat chronic, chronic colitis etc.

3. By rinse mouthwash with thermal water: chronic laryngitis and tonsylits of some gynecologic illness (Daci: 2006).

People come to Peshkopi thermal waters for another water course draining. He is called Cold Water spas and is located about a kilometer from the balneal center. For all those patients who have rheumatism in the initial stage, it's better to stay a few minutes to consult the source, which also has the temperatature $10^{\circ} \mathrm{C}$ on July. Besides water, numerous requirements are also black mud resulting from thermal water, which is used mainly for rheumatoid problems, women for ovarian warming etc. There are cases treated patients who come to these thermal waters for about 50 consecutive years who say they have life from thermal waters (Data from Peshkopia spa tourism).

Table 1. Chemical composition and physical properties of the thermal waters of Peshkopi.

\begin{tabular}{|l|c|l|c|}
\hline Physical parameters & Average & Chemical parameters & Average \\
\hline Temperature & $32^{\circ} \mathrm{C}$ & Sodium Na & $0.27 \mathrm{~g} / \mathrm{l}$ \\
\hline $\mathrm{pH}$ & 6.3 & Potash K & $0.05 \mathrm{~g} / \mathrm{l}$ \\
\hline Bromium $\mathrm{Br}$ & - & Magnesium $\mathrm{Mg}$ & $0.09 \mathrm{~g} / \mathrm{l}$ \\
\hline Radon $\mathrm{R}$ & - & Calcium Ca & $0.82 \mathrm{~g} / \mathrm{l}$ \\
\hline Carbon Dioxide & $0.54 \%$ & Chlorine $\mathrm{Cl}$ & $0.48 \mathrm{~g} / \mathrm{l}$ \\
\hline Sulphide Acid & $0.49 \mathrm{~g} / \mathrm{l}$ & Nitrate $\mathrm{NO}_{3}$ & - \\
\hline TDS (salts) & $4.05 \mathrm{~g} / \mathrm{l}$ & Sulfate $\mathrm{SO}_{4}$ & $1.68 \mathrm{~g} / \mathrm{l}$ \\
\hline Amone & $0.0014 \mathrm{~g} / \mathrm{l}$ & Bicarbonate $\mathrm{HCO}_{3}$ & - \\
\hline
\end{tabular}

Source: AKBN. (2010). Geothermal Resources. Tirana 2012. 


\section{Regulation of Thermal Bathing Water}

The patient who wants to perform treatment with thermal water, should have completed medical examination and be recommended to treat with this water. Treatment with thermal water is 10-14 daily sessions and continues for at least 5 consecutive years. The best effect is taken with a bathroom in the day. Washing procedure begins with filling the tub where the water is stopped (closed tap). The time spent in the bathtub with water is determined individually. The average stay in the water with $39-40^{\circ} \mathrm{C}$ is, 10 minutes on the first day, second day 11 minutes, third day 12 minutes, fourth day 13 minutes, 14 minutes on the fifth day, the sixth day 15 minutes and after this day washing time doesn't grow. Time for a washing is on average 30 minutes (stripping, washing, clothing). Patients constantly are checked by medical staff to avoid cases of asphyxia.After bathing the patient wrappe in towels without being and rest in bed or rest rooms up to an hour. It is not to be washed two people on one bathtube, except in case at medical recommendation. Also prohibited is the entry of persons under 14 years old without written medical recommendation. Where appear dizziness, feeling fainting, frequent heart beats, shortness of breath or sweat numerous, the bathroom should be stopped immediately and seek medical assistance to service personnel. Any person who makes the bathroom should be equipped with a ticket or payment terms (Regulation of Peshkopia spa tourism: 2012).

\section{The Attendance}

The number of visitors admitted for year is about 6000 (2014) with 10-14 day cycle, where more than 500 of them are coming from abroad, mainly from Macedonia (Peshkopia Municipality: 2010). The period with the highest number is with the average temperatures. Their number has been steadily increasing, while in recent years there is a slight decline due to the economic crisis. The existence of these resources has given the name of the neighborhood where they live.

The districts that have more patients in this baths are: Shkodra, Mati, Tropoja, Puka, Kukës, Mirdita, Lezha, Kurbini, Tirana, Durres, Fier, etc., But also from Kosovo and Macedonia. Over $80 \%$ of them are accommodated in private homes of residents living around. Also have been built and are being built several large hotels and modern capacities for accommodating visitors around the balneal center or even in the city of Peshkopi (Data from Peshkopia spa tourism).

Table 2. User ambulance in 2009-2011.

\begin{tabular}{|c|c|c|c|c|}
\hline \multirow{2}{*}{ Month } & \multicolumn{3}{|c|}{ Year } & \multirow{2}{*}{ Average for month } \\
\cline { 2 - 4 } & $\mathbf{2 0 0 9}$ & $\mathbf{2 0 1 0}$ & $\mathbf{2 0 1 1}$ & 24 \\
\hline Junuary & 22 & 28 & 23 & 43 \\
\hline February & 51 & 41 & 36 & 210 \\
\hline March & 145 & 247 & 238 & 1422 \\
\hline April & 1405 & 1565 & 1297 & 1302 \\
\hline May & 1470 & 1244 & 1192 & 303 \\
\hline June & 311 & 331 & 267 & 92 \\
\hline July & 79 & 96 & 100 & 142 \\
\hline August & 142 & 130 & 154 & 213 \\
\hline September & 299 & 188 & 153 & 193 \\
\hline October & 203 & 191 & 185 & 345 \\
\hline November & 344 & 319 & 372 & 97 \\
\hline December & 111 & 82 & 97 & 365 \\
\hline Total & 4582 & 4462 & 4114 & \\
\hline
\end{tabular}

Source: Peshkopia spa tourism.

As seen from the above data, attendance at this balneal center is during all the year. The highest number of visitors is during spring and particularly in April and May, while the period with the lowest number is the coldest period of the year, particularly in January and February. Near the center they are also several nature and cultural monuments like caves and springs at Bellova, Boroviku of Begjunecit-Rabdishtë, Gradishta Bellova, Gradishta Peshkopi etc. Also of interest to tourists appear the mountain villages of the Melan administrative unit as Zagrad, Bellova, Cerjan and Rabdisht. They are characteristics villages houses, their roofs and roads are all stone work by masters. Also they can visit the mountains near these villages, with diverse and attractive forms of relief and rich traditional cuisine of the area. 


\section{Economic Assessment}

On average a person is cured 10 days and the price is from 15000 to 20000 Lekë (1Euro=140 Lekë) including accommodation, meals and bathing. Many citizens of the neighborhood "Thermal Waters" have turned their villas in hostels for vacationers in the thermal waters. They have built their homes in the area after the fall of communism in Albania and free movement of people. Residents of this area are mainly coming from mountain villages at Melan administrative unit. After the migration of the workforce and ensuring revenues from external migration, a significant proportion of them have invested in the area near the thermal waters by building numerous villas. Mainly 2-3 storey villas, where residents live in one apartment, while other rooms give for rent to these guests. This has led to a significant number of self-employed in various transport services to tourists, sellers near this area, production and marketing of handicraft products of the area.

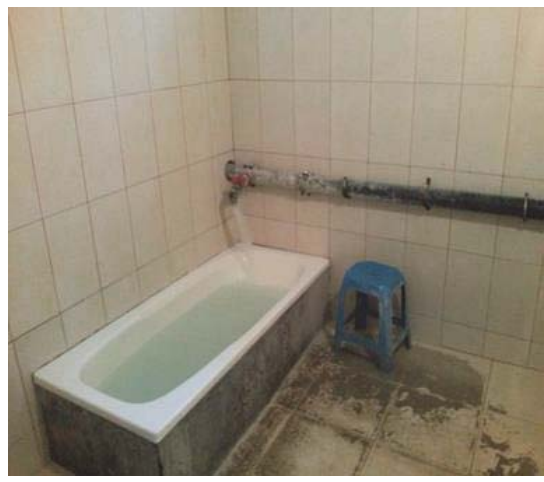

Figure 3. Thermal water tub with mud sulfur.

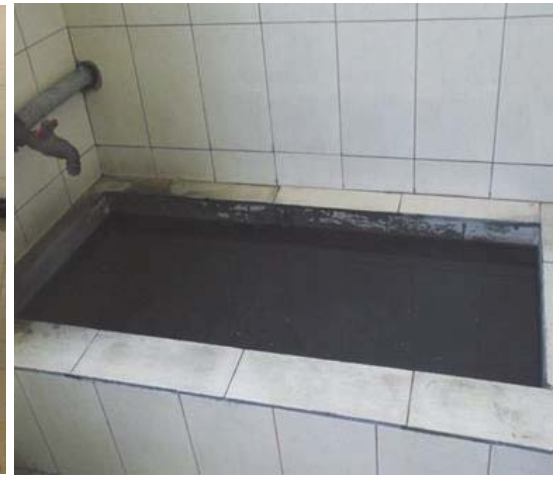

Figure 4. Coating skin.

By calculating the number of vacationers who treated every year and economic costs for a person, are provided a large income for the local community and municipality or in the form of taxes. Peshkopi spas with good management and investments where be necessary, have the potential to turn into the most important curative center in Albania. A real opportunity would be the end of the "Route of Arbër" which would shorten the distance with the capital in less than two hours after the travel time on the existing road is approximately four hours and in bad condition.

\section{Their Management}

Balneology complex includes the following services:

a. Hotel. Current capacity of the hotel includes 80 beds. In the hotel there are common toilets and individual. The thermal water reaches the hotel through plastic tubes from the main source. The hotel is currently part of the state property of curative center. There are also built other hotels, vacation homes, administered privately by individuals who have secured permission from the municipality of Dibër or exercise their activity illegally.

b. Restaurant. In curative complex is located the restaurant which serves healthy food and drink to patients who are hospitalized there for a period of 10-14 days. The restaurants in the private hotels function in the same way.

c. Washing baths with thermal water. There are 44 washing tanks and a pool with length of $10 \mathrm{~m}$ and width of 8 $\mathrm{m}$. Tanks are usually individual, but has rooms with double bathtubs. Thermal water reaches these tanks through pipes from the source. When the water runs through pipes in tanks, temperatures goes down to $39^{\circ} \mathrm{C}$. Curative capacity reaches up to 2000 washing a day especially during May-June and September-October. Standing in the tub lasts 10 to 15 minutes at a temperature of $39-40^{\circ} \mathrm{C}$. The development of this center should consist in rebuilding and restructuring of the hotel and clinic to give her medical settings, living and comfort in accordance with the requirements and today's level of analogue centers (Data from Peshkopia spa tourism). 
Table 3. Some of the hotels that expect to spa resort.

\begin{tabular}{|c|c|c|c|c|c|}
\hline Hotel & Number of rooms & Number of beds & Single rooms & Rooms $\geq \mathbf{2}$ & Address \\
\hline Klajdi & 49 & 117 & 45 & 113 & Dobrovë \\
\hline Natyra e Qetë & 20 & 80 & 5 & 25 & Llixha \\
\hline Ballkan & 40 & 106 & 4 & 8 & Llixha \\
\hline Alpin & 35 & 70 & 12 & 23 & Llixha \\
\hline L. Nela & 10 & 22 & 8 & 2 & Llixha \\
\hline Termal & 22 & 60 & 12 & 10 & Llixha \\
\hline Reian & 15 & 33 & 10 & 5 & Llixha \\
\hline Modena & 21 & 50 & 15 & 6 & Llixha \\
\hline Jashari & 8 & 20 & 6 & 2 & Llixha \\
\hline Tetova & 20 & 50 & 12 & 8 & Llixha \\
\hline Sadri Sela & 6 & 17 & 4 & 2 & Llixha \\
\hline Shtetëror i Llixhave & 25 & 80 & 22 & 3 & Llixha \\
\hline A. Nela & 14 & 35 & 0 & 14 & Llixha \\
\hline Total & $\mathbf{2 8 5}$ & $\mathbf{7 4 0}$ & $\mathbf{1 5 5}$ & $\mathbf{2 2 1}$ & - \\
\hline
\end{tabular}

Source: Dibër Regional Council. (2014).

In balneary complex of thermal waters are serving 35 employees and board of directors of five people. The building built in balneary complex has a capacity of 100 beds. The annual revenues has a total at $125-130$ million for year. About $20 \%$ of income exceede the municipality in the tax form (Peshkopia Municipality: 2010). Incomes are spent on payments at employees or investments and maintenance of the spa tourism. Balneological center at Peshkopi can become a renewal establishment curative, and tourism outstanding treatment abroad, initially even to the level at balneological center at Kosovrasti and Banjishti in Dibër area in Macedonia (Frashëri \& Kodhelaj: 2010).

Some of the current problems of Peshkopi balneal center are: damages and cracks in the network of thermal waters, new construction, especially around thermal springs, trenching illegal jeopardizing lowering their quality, row over the introduction in bathtubs especially during the period when the influx of vacationers and lead the necessity of increasing the number of tubs. All cabinets that work and those that can be put to work within investment material definitely require specialized nursing personnel under specific therapeutic procedures.

\section{Conclusions}

Peshkopi thermal waters present quite therapeutic value being recommended for a number of diseases such as skin, digestive tract, genetics etc. Because they are part of the curative type of tourism, the tourism sector represent the most developed and most frequented tourism in the district of Dibër. Besides the fact that many holidaymakers have found a cure for these thermal waters, their presence has become a major source of income for most residents of the surrounding area and beyond.

It stands for a high number of vacationers throughout the year, but the period that has the largest influx is during spring and autumn, related to relationship with climatic conditions suitable. Holidaymakers except Dibra or other districts of the country come from Kosovo or Macedonia. Most of them are accommodated in the homes of nearby residents. There appear great prospects in the number of tourists or investments that are expected to be developed especially by the construction of "Road of Arbër" which will draw him close to the capital about $100 \mathrm{~km}$ that would have made them more accessible to all the Albanian regions and beyond.

By studying this article, we come to the result that thermal waters of Peshkopi are one of the most important and curative sources in Albania. Their exsistence also is an important source of incomes for the people and the municipality of Dibra.

\section{References}

Albanian Academy of Sciences. (1990). Physical Geography of Albania. Tirana, Vol.I, p.259.

AKBN. (2012). Geothermal Resources. Tirana.

Daci, F. (2006). Encyclopedia of Dibra. Tirana, Vol.I, p.15-38.

Data from Dibër Regional Council, Department of Planning and Regional Development. (2010-2015). Peshkopi. 
Data from Peshkopia spa tourism. (2008-2016). Peshkopi.

Decision no. 676, dt 20.12.2002 "For the protected area of albanian monuments of nature".

Doka, Dh., \& Draçi, B. (2002). Geography of tourism. Tirana.

Doka, Dh. (1996). Civil tourism and tourism values of albanian cities. Tirana.

Frashëri, A., \& Kodhelaj N. (2010). Platform for projecting of integrated and cascade use of geothermal energy of low enthalpy in Albania. Tirana.

Group of authors. (2003). Geological heritage and geotourism in Albania. Tirana.

Intellectuals Association Connecting Dibër. (2007). Route of Arbër. Tirana.

Ministry of Environment. (2014). Natural Mountains Ecosystem "Korab-Koritnik natural park", Menagement plan. Tirana.

Peshkopia Municipality. (2010). Local action plan for biodiversity. Peshkopi, p.16.

Peshkopia Municipality. (2010). Tourist Guide. Tirana, p.22-23.

Polytechnic University of Tirana, Faculty of Geology and Mining. (2004). Atlas of the geothermal resources in Albania. Tirana, p.38.

UNDP. (2012). Regional Development Strategy 2012-2016, Dibër Regional Council. 